\title{
THE PHENOLIC ACIDS OF SOME SPECIES OF THE OENOTHERA L. GENUS
}

\author{
TADEUSZ KRZACZEK ${ }^{1}$, ANNA BOGUCKA-KOCKA ${ }^{1}$, RENATA ŚNIEŻKO² \\ ${ }^{1}$ Department of Pharmaceutical Botany, Medical Academy, \\ Staszica 4, 20-081 Lublin, Poland \\ ${ }^{2}$ Institute of Biology Maria Curie-Skodowska University, \\ Akademicka 19, 20-033 Lublin, Poland
}

(Received: September 28, 1994. Accepted: February 10, 1995)

\begin{abstract}
The occurence and approximative quantitative proportions of the phenolic acids in four species of the Oenothera L. genus was determined by the method of TLC and HPLC. In all species of Oenothera L. genus the permanent occurrence of acids: 2-hydroxy-4-metoxybenzoic, salicylic, ferulic, syringic, vanillic, p-coumaric, p-hydroxybenzoic, p-hydroxyphenylacetic, $\gamma$-rezorcil, gentysic, protocatechuic, caffeic and gallic has been confirmed. Whereas the other phenolic acids: o-coumaric, o-hydroxyphenylacetic and pirocatechuic were found in some species of the Oenothera L. genus only.
\end{abstract}

KEY WORDS: Oenothera species, phenolic acids.

\section{INTRODUCTION}

The present interest in the Oenothera $\mathrm{L}$. is the effect of the mixture of fatty acids, contained in the oil obtained from seeds. Oenothera is known in therapeutics for a long time but so far its use has been connected with non-oil substances contained in its roots or herbs. The dietetic values of this plant were also important. The roots of Oenothera were often used, because their taste resembled that of ham (Madaus 1938). In Ukraine, Belorussia and France the fresh raw roots are recommended as a tasty, valuable vegetable (Franke 1981). The decoction of dry roots is mainly adhibited in the case of problems respiratory tracts, and the decoction of dry herbs in cases of diarhoea and nephritis (Lamer-Zarawska and Hojden 1989). In other areas of the world the herb of Oenothera is used as an anti-diarrhoeic remedy (Hoppe 1975) and infusion of herbs is recommended in the case of problems with chronic inflammation of urinary passages and alimentary canal, in asthma and pertussis (Milispangh 1974).

The repeated tests and new interest in this plant by Heiduszek and Lüft in 1919 (Lamer-Zarawska and Hojden 1989) showed, that the seeds of Oenothera contain $\gamma$-linoleic acid. The average oil content in seeds of this plant is 24\% (Hudson 1984), but some sources say, that there are varieties, which contain $30 \%$ of oil (Wolf 1983). This oil contains triglycerydes $(97-98 \%)$, unsaponifiable substances $(1,5-2,0 \%)$ and polar lipides $(0,5-1,0 \%)$ with $\gamma$-linoleic acid $(7-14 \%)$ and linolenic acid (65-85\%) (Hudson 1984). The seeds of the Oenothera contain also proteins $(15,2 \%)$, starch, dextrin and sugars $(5,6 \%)$, cellulose $(27 \%)$, lignin $(16 \%)$ and water $(8,3 \%)$ (Hudson 1984).

Chromatographic methods showed, that leaves of Oenothera biennis contain phenolic acids, flavonoids (Szepczyńska and Wolbiś 1992) and caoutchouc (Hegnauer
1969), whereas herbs contain organic acids and tannins (Hegnauer 1969). Some pharmacological properties of seeds of this plant may depend on the presence of phenolic acids (Lamer-Zarawska and Hojden 1989) - this is why our studies on the presence of phenolic acids in seeds and in herbs of four Oenothera species has been undertaken.

\section{MATERIALS AND METHODS}

Herbs and seeds of four species of Oenothera L. Oenothera biennis L., Oenothera lamarckiana L., Oenothera suaveolens Desf. ex Pers. and Oenothera hookeri Torn. were used in our study. The pure genetic plants grew in the experimental garden of the Institute of Developmental Biology in Kolonia and later they were cultivated owing to selffertilization in the experimental garden of the Institute of Biology Maria Curie-Skodowska University in Lublin.

The plant materials were dried in natural conditions and later were pulverized in an electrical mill.

Phenolic acids were isolated according to the method of Ibrahim and Towers (1960) as used by Krzaczek (1984). At the beginning $60 \mathrm{~g}$ of seeds and $36 \mathrm{~g}$ of herbs from each species were extracted twice with sevenfold vol/vol $80 \%$ methanol at boiling point of the dissolvent for $1 \mathrm{hr}$. Later the extracts were mixed and methanol was distilled. The remains were diluted with boiling water and they stayed in room temperature for $24 \mathrm{hrs}$.

Then the sediment was filtered trough filter paper. The filtrate was purified by repeated washing with petroleum ether. The purified aqueous solution was extracted with diethyl ether exhaustively. The ether layer was washed out with $5 \%$ aqueous solution of $\mathrm{NaHCO}_{3}$. The carbonate layer was acidified with $10 \% \mathrm{HCl}$ to $\mathrm{pH} 3$ and free acids were extracted by diethyl ether. The extract was dried with anhydrous $\mathrm{Na}_{2} \mathrm{SO}_{4}$ 
TABLE 1. The occurence of phenolic acids in fractions of species Oenothera L. genus.

Explanation: + small amount, ++ average amount, +++ large amount.

A - free phenolic acids fractions, B - acid hydrolysis after phenolic acids fractions, $\mathrm{C}$ - alkaline hydrolysis after phenolic acids fractions s fraction from seeds, $\mathrm{h}$ - fraction from herb

PHENOLIC Oenothera biennis Oenothera lamarckiana Oenothera suaveolens $\quad$ Oenothera hookeri
ACIDS

\begin{tabular}{|c|c|c|c|c|c|c|c|c|c|c|c|c|c|c|c|c|c|c|c|c|c|c|c|c|}
\hline & As & $\mathrm{Ah}$ & Bs & $\mathrm{Bh}$ & Cs & $\mathrm{Ch}$ & As & Ah & Bs & $\mathrm{Bh}$ & $\mathrm{Cs}$ & $\mathrm{Ch}$ & As & $\mathrm{Ah}$ & Bs & $\mathrm{Bh}$ & Cs & $\mathrm{Ch}$ & As & $\mathrm{Ah}$ & Bs & $\mathrm{Bh}$ & $\mathrm{Cs}$ & $\mathrm{Ch}$ \\
\hline 1. gallic & +++ & + & ++ & ++ & ++ & +++ & +++ & & ++ & ++ & +++ & +++ & +++ & + & + & ++ & ++ & +++ & +++ & + & + & ++ & ++ & + \\
\hline 2. caffeic & ++ & + & ++ & ++ & + & +++ & +++ & + & + & ++ & ++ & +++ & +++ & + & ++ & +++ & +++ & +++ & ++ & +++ & ++ & +++ & ++ & +++ \\
\hline 3. proto- & & & & & & & & & & & & & & & & & & & & & & & & \\
\hline catechuic & + & ++ & + & + & + & + & + & & + & + & ++ & + & + & + & + & + & + & + & + & + & + & + & + & + \\
\hline 4. gentysic & & & & ++ & & + & & & & ++ & & + & & + & & +++ & & + & & + & & +++ & & +++ \\
\hline 5. $\gamma$-rezorcil & & & & + & & & & & & + & & & & & & + & & & & & & + & & \\
\hline 6. p-hydroxy- & & & & & & & & & & & & & & & & & & & & & & & & \\
\hline phenylacetic & & & + & ++ & & & & & + & + & & & & & + & + & & & + & & + & ++ & & \\
\hline 7. p-hydroxy- & & & & & & & & & & & & & & & & & & & & & & & & \\
\hline benzoic & +++ & + & ++ & + & + & ++ & ++ & ++ & + & ++ & + & ++ & +++ & + & ++ & ++ & ++ & + & ++ & ++ & ++ & + & + & ++ \\
\hline 8. p-coumaric & + & + & + & + & + & ++ & ++ & & + & + & ++ & ++ & ++ & ++ & + & + & ++ & +++ & +++ & + & ++ & + & +++ & ++ \\
\hline 9. pirocatechuic & + & + & & & & & & & & + & & & + & + & & + & & & + & & & & & \\
\hline 10. o-coumaric & + & & & & & & + & & & & & & + & & & & + & & & & & & & \\
\hline $\begin{array}{l}\text { 11. o-hydro- } \\
\text { xypheny- }\end{array}$ & & & & & & & & & & & & & & & & & & & & & & & & \\
\hline lacetic & & & & & & & & & & + & & & & & & + & & & & & & + & & \\
\hline 12. vanillic & +++ & + & ++ & ++ & ++ & ++ & ++ & + & ++ & ++ & ++ & + & +++ & + & ++ & ++ & ++ & + & +++ & + & ++ & ++ & ++ & + \\
\hline 13. syringic & & + & + & ++ & + & + & & & + & + & ++ & ++ & ++ & & + & + & + & ++ & ++ & + & + & + & ++ & ++ \\
\hline 14. ferulic & ++ & ++ & ++ & ++ & +++ & +++ & ++ & +++ & ++ & +++ & +++ & +++ & +++ & ++ & ++ & +++ & +++ & +++ & +++ & ++ & ++ & +++ & +++ & +++ \\
\hline 15. salicylic & ++ & ++ & + & & + & & + & & + & & & & + & ++ & & ++ & & + & ++ & & + & & + & \\
\hline $\begin{array}{l}\text { 16. 2-hydroxy- } \\
\text { 4-metoxy- }\end{array}$ & & & & & & & & & & & & & & & & & & & & & & & & \\
\hline benzoic & + & & + & & + & & + & & + & + & + & + & + & & + & & + & & + & + & & + & & \\
\hline
\end{tabular}

and the ether was evaporated. The remnants were dissolved in $3 \mathrm{ml}$ of ethanol and were indicated: $\mathrm{A}_{\mathrm{s}}$ fraction (from seeds) and $A_{h}$ fraction (from herbs) and were used for chromatography. The residual aqueous eluates after $A_{S}$ and $A_{h}$ fraction extraction were divided into two parts, they were separated in alkaline and acid hydrolysis (Schmidtlein and Herrman 1985).

One half of the aqueous solution was subjected to acid hydrolysis with $98 \% \mathrm{H}_{2} \mathrm{SO}_{4}(6 \mathrm{ml} / 100 \mathrm{ml}$ of extracts) in boiling water both for $2 \mathrm{hr}$. Next the eluent was extracted by diethyl ether exhaustively and were indicated: $B_{s}$ fraction (from seeds) and $\mathrm{B}_{\mathrm{h}}$ fraction (from herbs). The remaining half of the aqueous solution was subjected to alkaline hydrolysis with sodium borohydride $(0,8 \mathrm{~g} / 100 \mathrm{ml}$ of extracts) and alkalized with a saturated solution of barium hydroxide to $\mathrm{pH} \mathrm{12-13}$. The obtained solution was warmed in boiling water both for $15 \mathrm{~min}$. and next was extracted by diethyl ether exhaustively. The fractions of phenolic acids liberated the alkaline hydrolysis after were indicated: $\mathrm{C}_{\mathrm{s}}$ fraction (from seeds) and $\mathrm{C}_{\mathrm{h}}$ (from herbs) - analogical as above.

The $A_{s}, A_{h}, B_{s}, B_{h}, C_{s}$ and $C_{h}$ fractions were investigated with two methods: two-dimenstional thin-layer chromatography (TLC) and high performance liquid chromatography (HPLC).

1. Two-dimenstional TLC (Smolarz and WaksmundzkaHajnos 1993) on plates with $0.1 \mathrm{~mm}$ layer of cellulose pow- der coated. The cellulose-coated plates were run in DS-type chambers in the following phases:

I direction: benzene - methanol - acetic acid - acetonitryl $80: 5: 5$ : 5 and

II direction: sodium formate - formic acid - water $10: 1: 200$.

The position of the phenolic acid spots on chromatograms was analysed using UV-light (about $366 \mathrm{~nm}$ ) before and after exposure to ammonium vapors and daylight after spraying with the following developers:

- diazotized sulphanilic acid in 20\% $\mathrm{Na}_{2} \mathrm{CO}_{3}$ (Bray 1950, Linskens 1959),

- diazotized p-nitroaninline (Randterath 1962) and

- $2 \%$ aqueous $\mathrm{FeCl}_{3}$ solution (Jerzmanowska 1961).

The quantitative proportion of the phenolic acid found by us (Tab. 1) was stated on the ground of size of the spots and the intensity of the colour (Krzaczek and Krzaczek 1979, Świątek 1970), (Fig. 1).

2. The HPLC was performed in 1050 Hewlett Packard chromatograph with UV-Vis crystal set and Rheodyne valve, with the Hypersil ODS $200 \mathrm{~mm}$ length and 4,6 mm diameter column, $5 \mu \mathrm{m}$ thick of granules and 3396 Integrator HP at the rate of $0,5 / \mathrm{min}$ tape transfer (Fig. 2). The mobile phases was methanol - water $(25: 75)$ with $5 \% \mathrm{vol} / \mathrm{vol}$ acetic acid (Głowniak and Zgórka 1993). The detection of phenolic acid 


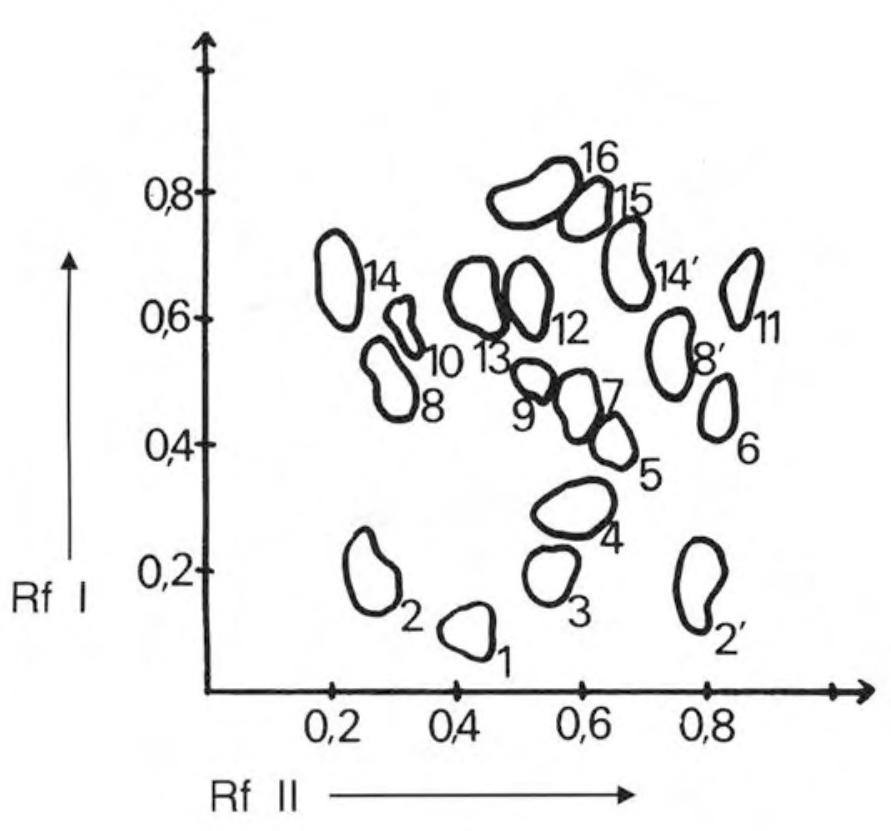

Fig. 1. Two-dimensional thin layer chromatogram of phenolic acids of species Oenothera L. genus. Number and staining of spots are given in Table 1. The cisisomers are marked with apostroph.

was registred using $\gamma=254 \mathrm{~nm}$ and was identified on the ground of the corresponding standards.

\section{RESULTS AND DISCUSSION}

The TLC and HPLC chromatographic methods of tests showed the proportion of phenolic acids in four species of the Oenothera L.: Oenothera biennis L., Oenothera lamarckiana L., Oenothera suaveolens Desf. ex Pers. and Oenothera hookeri Torn. In general 16 phenolic acids were identified. The occurrence of acids: salicylic, p-hydroxybenzoic, protocatechuic, vanillic, gentisic, p-coumaric, caffeic, ferulic and p-hydroxyphenylacetic was found earlier in leaves of Oenothera biennis L. by Szepczyńska and Wolbiś (1992).

In our investigations the gallic, caffeic, protocatechuic, phydroxyphenylacetic, p-hydroxybenzoic, p-coumaric, vanillic, syryngic and ferulic acids occurred regularly in herbs and seeds of the species being examined.

The o-coumaric acid ocurred only in seeds. We have not observed the gentisic, $\gamma$-rezorcylic and o-hydroxyphenylacetic acids in seed fractions of all Oenothera species. The o-hydroxyphenylacetic acid was not found in Oenothera biennis L. and o-coumaric acid in Oenothera hookeri L. in no fractions from seeds and herbs.

In seeds the gallic and vanillic acids, and in herbs the caffeic and ferulic acids predominated.

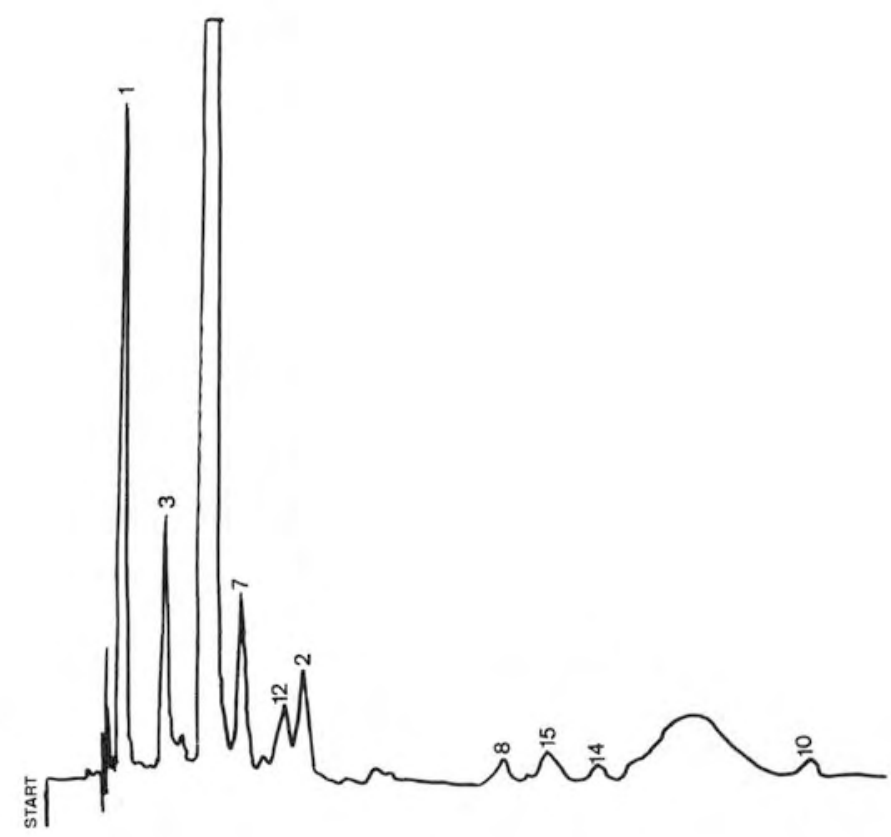

Fig. 2. High performance liquid chromatography of phenolic acids from $\mathrm{A}_{\mathrm{s}}$ fraction from seeds of Oenothera biennis L. The number of peaks are given in Table 1.

Most of the phenolic acids show pharmacological activity. Considering the therapeutical effect of plant material the following acids are conspicuous:

- p-hydroxybenzoic, vanillic, p-coumaric and caffeic acids antibacterial activity (Masquelier and Delaunay 1965)

- ferulic acid - cholagogue activity (Kohlmünzer 1985) and

- salicilic acid - antibacterial, antiphlogistic and antipyretic activities (Negver 1978).

\section{LITERATURE CITED}

BRAY H.G., THORPE W.V., WHITE K., 1950. Fate of certain organic acids and amides in the rabbit. X. pplication of paper chromatography to metabolic studies of hydroxybenzoic acids and amides. Biochem. J. 46: 271.

FRANKE W., 1981. Nutzpflanzenkunde. Stuttgart - New York.

GŁOWNIAK K., ZGÓRKA G., 1993. Zastosowanie HPLC do oceny składu frakcji fenolokwasów wyodrębnionych z liści orlika pospolitego - Aquilegia vulgaris L. (Ranunculaceae). II Ogólnopolska Konferencja Naukowa nt Zastosowanie Metod Chromatograficznych w Badaniach Fitochemicznych i Biomedycznych. Streszczenia. 24 czerwca 1993. Akademia Medyczna w Lublinie Wydział Farmaceutyczny. (in Polish)

HEGNAUER R., 1969. Chemotaxonomie der Pflanzen, Bd 5. Birkhäuser Verlag. Stuttgart.

HOPPE H., 1975. Drogenkunde. W. de Gruyter, Berlin - New York. HUDSON B.J.F., 1984. Evening primrose oil and seeds. JAOCS, 61: 540-543. 
IBRAHIM R.K., TOWERS G.H., 1960. Identification by chromatography of plant phenolic acids. Arch. Bioch. Biophys. 87: 125-131.

JERZMANOWSKA Z., 1961. Substancje roślinne. Metody wyodrębniania. PWN, Warszawa. (In Polish)

KOHLMÜNZER S., 1985. Farmakognozja. PZWL, Warszawa.

KRZACZEK W., KRZACZEK T., 1979. Phenolic acids of native species of the Rosa L. genus in Poland. Acta Soc. Bot. Pol. 18: 327 337.

KRZACZEK T., 1984. Fenolokwasy w niektórych surowcach garbnikowych z rodziny Rosacae. Farmacja Pol. 40: 76-85. (In Polish)

LAMER-ZARAWSKA E., HOJDEN B., 1989. Rośliny z rodzaju Oenothera L. źródłem niezbędnych nienasyconych kwasów tłuszczowych. Herba Pol. 2-3: 151-155. (in Polish)

LINSKENS H.F., 1959. Papierchromatographie in der Botanik. Springer - Verlag. Berlin - Götingen - Heidelberg.

MADAUS G., 1938. Lehrbuch der Biologischen Heilmittel, Georg Thieme Verl. Leipzig.

MASQUELIER J., DELAUNAY D., 1965. Bactericidal action of the phenolic acids of wine. Bull. Soc. Pharm. Bordeaux, 104: 152-160.

MILISPANGH C., 1974. American medicinal plants. Dover Publ. Inc., New York.
NEGVER M., 1978. Organic-chemical drugs and their synonymus. Academic Verlag, Berlin.

RANDERATH K., 1962. Dünschicht-Chromatographie. Verlag Chemie, Weinheim.

SCHMIDTLEIN H., HERRMAN K., 1975. Quantitative analysis for phenolic acids by thin layer chromatography. J. Chromatogr. 115: 123-128.

SMOLARZ H.D., WAKSMUNDZKA-HAJNOS M., 1993. Two-dimensional TLC of phenolic acids on cellulose. J. Planar Chromatogr. 4: 278-281.

SZEPCZYŃSKA K., WOLBIŚ M., 1992. Fenolokwasy i flawonoidy Oenothera biennis L. Materiały zjazdowe z XV. Naukowego Zjazdu Polskiego Towarzystwa Farmaceutycznego "Postępy nauk farmaceutycznych", Warszawa. (in Polish)

ŚWIĄTEK L., 1970. Pharmacobotanical investigation on some species of family Scrophulariaceae. Dissert. Fharm. Fharmacol. 22: 23-30.

WOLF R.B., KLEIMAN R., ENGLAND R.E., 1983. New sources of GLA. JAOCS, 60: 1858-2860.

\section{KWASY FENOLOWE W NIEKTÓRYCH GATUNKACH RODZAJU OENOTHERA L.}

\section{STRESZCZENIE}

Określono występowanie i proporcje ilościowe kwasów fenolowych w czterech gatunkach rodzaju Oenothera L. metodami chromatografii cienkowarstwowej (TLC) i wysokosprawnej chromatografii cieczowej (HPLC). We wszystkich badanych gatunkach stwierdzono stałe występowanie następujących kwasów fenolowych: 2-hydroksy-4-metoksybenzoesowego, salicylowego, ferulowego, syryngowego, wanilinowego, p-kumarowego, p-hydroksybenzoesowego, p-hydroksyfenylooctowego, $\gamma$-rezorcylowego, gentyzowego, protokatechowego, kawowego i galusowego. Natomiast kwasy: pirokatechowy, o-kumarowy i o-hydroksyfenylooctowy występoway tylko w niektórych gatunkach rodzaju Oenothera L.

SŁOWA KLUCZOWE: Oenothera, kwasy fenolowe. 